\title{
Pengaruh Citra Tubuh, Perilaku Makan, dan Aktivitas Fisik Terhadap Indeks Massa Tubuh (IMT) pada Remaja: Studi Kasus pada SMA Negeri 12 DKI Jakarta
}

\section{Effects of Body Image, Eating Behavior and Physical Activity on Body Mass Index of Teenagers: A Case Study among Students of SMA Negeri 22 DKI Jakarta}

\section{Muhammad Ridwan Hadi Kusuma, Tri Krianto}

Departemen Pendidikan Kesehatan dan Ilmu Perilaku, Fakultas Kesehatan Masyarakat Universitas Indonesia

\begin{abstract}
ABSTRAK
Latar Belakang. Pemahaman citra tubuh yang keliru tentang "kurus itu indah" menjadi idaman bagi remaja puteri. Hal ini sering menjadi penyebab masalah, karena untuk memelihara kelangsingan tubuhnya dan ketakutan menjadi gemuk mendorong remaja untuk menerapkan pembatasan makanan yang berlebihan, sehingga kebutuhan gizinya tidak terpenuhi yang nantinya akan berakibat terjadinya kurang gizi.

Tujuan. Tujuan penelitian ini adalah untuk mengetahui pengaruh citra tubuh terhadap perilaku makan dan Indeks Massa Tubuh (IMT) pada siswi SMA Negeri 12 Jakarta Timur kelas X dan XI tahun 2014.

Metode. Penelitian ini dilakukan pada bulan April-Mei 2014 dengan desain cross sectional, sampel penelitian adalah 238 siswi. Analisis data menggunakan analisis jalur.

Hasil. Hasil penelitian menunjukkan terdapatnya pengaruh citra tubuh terhadap IMT melalui perilaku makan dan aktivitas fisik, membuktikan bahwa citra tubuh tidak langsung berpengaruh terhadap IMT, namun masih harus dilihat bagaimana perilaku makan serta aktivitas fisik yang dilakukan oleh responden.
\end{abstract}

Kata kunci: analisis jalur, gizi, gangguan makan

\section{ABSTRACT}

Background. "Thin is beautiful" is an erroneous understanding of body image that becoming a dream for every teenage girl. This is often the cause of problems, because to maintain her slimness and fear of becoming obese encourage teenagers to apply excessive dietary restrictions, so that their nutritional needs are not met which will be result in the occurrence of malnutrition.

Objective. The aim of this studyis to determine the influence of body image against eating behavior and body mass index (BMI) among 10th and 11th grades 12th East Jakarta States Senior High School's female students in 2014.

Method. This study was conducted in April - May 2014, with cross sectional design, the study sample was 238 female students.

Results. The results of this study using path analysis concluded that the presence of the influence of body image against BMI through eating behavior and physical activity, proved that the body image does not directly influence the IMT, but remains to be seen how eating behavior and physical activity undertaken by respondents. Therefore, efforts are required to empower our teenagers by challenging unhealthy beliefs they may have regarding weight, shape, and eating behavior. In addition, there should be regular nutrition counseling activities for teenagers with education 
material about body image and eating behavior, especially on a balanced diet and ideal body weight for teenage girls.

Keywords: path analysis, nutrition, eating disorder

\section{LATAR BELAKANG}

Penampilan fisik seorang individu menjadi hal yang penting untuk remaja. Penilaian yang disebut dengan citra tubuh tersebut berupa perasaan puas atau tidak puas akan keadaan tubuh dan penampilannya. Citra tubuh (body image) diartikan sebagai pandangan dari penampilan fisik seseorang secara keseluruhan. Ketidaksesuaian antara bentuk tubuh yang dipersepsi oleh individu dengan bentuk tubuh yang menurutnya ideal akan memunculkan ketidakpuasan terhadap tubuhnya.

Penelitian sebelumnya mengungkapkan media memberikan dampak dalam persepsi remaja terhadap bentuk tubuh. Paparan dalam jangka waktu yang panjang terhadap majalah mode telah terbukti meningkatkan ketidakpuasan tubuh, tekanan persepsi untuk menjadi kurus, diet, dan gejala bulimia pada remaja. ${ }^{1}$ Selanjutnya, pengaruh media telah terbukti memiliki dampak lebih pada individu daripada pengaruh orangtua, terutama dalam hal yang berkaitan dengan citra tubuh. Pada akhirnya media massa dapat memberikan efek negatif baik langsung maupun tidak langsung terhadap tingkat depresi, gangguan makan, dan fungsi akademis. ${ }^{2}$

Sebagian besar remaja yang sering melakukan penilaian terhadap tubuhnya adalah perempuan, dan termasuk golongan sosial-ekonomi menengah ke atas dimana mereka sangat peduli akan bentuk tubuh dan berat badan mereka. Remaja putri lebih banyak mengalami gangguan makan dibandingkan dengan remaja putra dengan perbandingan 10:1. Daya tarik fisik untuk perempuan juga telah terbukti lebih berhubungan dengan berat badan dan bentuk tubuh daripada karakteristik fisik seperti rambut, wajah, dan lain-lain.

Dilaporkan 1 dari 100 remaja putri yang berumur antara 16-18 tahun menderita Anorexia Nervosa (AN). ${ }^{3}$ Puncak angka kejadian AN pada remaja adalah pada umur 14,5 tahun dan 18 tahun, 25\% kasus AN lebih banyak terjadi pada remaja umur lebih muda yaitu di bawah 13 tahun. Hampir 50\% remaja tidak sarapan. Walaupun 89\% remaja meyakini bahwa sarapan penting, namun hanya $60 \%$ yang sarapan secara teratur.

Ketakutan menjadi gemuk mendorong remaja untuk menerapkan pembatasan makanan yang berlebihan. Masalah kurang gizi dapat berupa kekurangan energi dan protein, kurus, obesitas, maupun tinggi badan yang tidak sesuai dengan umur. Secara nasional rata-rata kecukupan konsumsi energi penduduk usia 16 -18 tahun berkisar antara 69,5\% $84,3 \%$, dan sebanyak $54,5 \%$ remaja mengonsumsi energi dibawah kebutuhan minimal. Sedangkan ratarata kecukupan konsumsi protein remaja berkisar antara $88,3 \%-129,6 \%$, dan remaja yang mengonsumsi dibawah kebutuhan minimal sebanyak 35,6\%. Prevalensi pendek pada remaja adalah $31,4 \%$ (7,5\% sangat pendek dan $23,9 \%$ pendek), sedangkan prevalensi kurus pada remaja sebesar 9,4\% (1,9\% sangat kurus dan 7,5\% kurus). Prevalensi gemuk pada remaja sebanyak $7,3 \%$ yang terdiri dari $5,7 \%$ gemuk dan $1,6 \%$ obesitas.

Remaja yang memiliki citra tubuh negatif cenderung memiliki perilaku makan yang tidak baik sehingga berakibat pada berbagai masalah kekurangan gizi. Masalah kurang gizi tersebut dapat berupa kekurangan energi dan protein, kurus, obesitas, maupun tinggi badan yang tidak sesuai dengan umur. Melihat masalah tersebut maka perlu penelitian mengenai pengaruh citra tubuh, perilaku makan, dan aktivitas fisik terhadap IMT pada siswi SMA Negeri 12 Jakarta Timur kelas X dan XI.

Tujuan penelitian yaitu untuk mengetahui pengaruh citra tubuh, perilaku makan, dan aktivitas fisik terhadap IMT pada siswi SMA Negeri 12 Jakarta Timur kelas X dan XI.

\section{METODE}

Penelitian ini merupakan penelitian kuantitatif observatif, menggunakan data hasil wawancara dengan kuesioner dan pengukuran. Rancangan penelitian ini menggunakan desain cross sectional. Populasi penelitian adalah seluruh remaja putri kelas X dan XI di SMA Negeri 12 Jakarta Timur tahun 2014 dengan total populasi sebanyak 252 orang. Seluruh remaja putri yang memenuhi kriteria inklusi digunakan sebagai sampel penelitian. Indeks Massa Tubuh (IMT) sebagai outcome dalam penelitian ini akan menjadi variabel dependen endogenous, sementara itu perilaku makan dan aktivitas fisik merupakan perilaku dari siswi kelas X dan XI SMA Negeri 12 Jakarta Timur 
yang diduga akan mempengaruhi IMT dan dipengaruhi oleh health attitudes berupa citra tubuh, dengan pengaruh media massa dan pengaruh teman sebagai variabel independen exogenous yang diduga akan mempengaruhi citra tubuh.

Pengukuran IMT melalui metode antopometri meliputi pengukuran berat badan dan tinggi badan. Pengukuran berat badan dilakukan dengan menggunakan timbangan merk Seca dengan ketelitian $0,1 \mathrm{~kg}$, dan pengukuran tinggi badan dilakukan menggunakan microtoise dengan ketelitian $0,1 \mathrm{~cm}$. Kedua instrumen tersebut sebelumnya dikalibrasi terlebih dahulu. Peng-ukuran citra tubuh dilakukan dengan mengguna-kan kuesioner adaptasi Multidimensional Body Self Relation QuestionnaireAppearance Scales (MBSRQ-AS). MBSRQ-AS merupakan self-report inventori yang terdiri 34 item untuk mengukur aspek sikap terhadap penampilan fisik terkait konstruk citra tubuh. MBSRQ-AS terdiri dari 2 dimensi utama, yaitu: Appearance Evaluation dan Appearance Orientation. Selain itu, terdapat 3 dimensi tambahan dalam MBSRQ-AS, antara lain Body Areas Satisfaction, Overweight Preoccupation dan SelfClassified Weight. ${ }^{4}$

Pengukuran pengaruh media massa dilakukan dengan menggunakan kuesioner adaptasi Sociocultural Attitudes Towards Appearance Scale Questionnaire-3 (SATAQ-3). SATAQ-3 terdiri dari 4 dimensi, yaitu: Information, Pressures, Internalization-Athlete, dan Internalization-General (Thompson et.al., 2004). ${ }^{5}$

Pengukuran pengaruh teman dilakukan dengan menggunakan kuesioner Sikap terhadap Pengaruh Teman. Kuesioner ini merupakan buatan peneliti yang sebelum digunakan dalam penelitian ini terlebih dahulu telah diuji validitas dan reliabilitasnya.

Pengukuran perilaku makan dilakukan dengan menggunakan kuesioner adaptasi Eating Attitudes Test26 (EAT-26). EAT-26 merupakan kuesioner yang secara luas digunakan sebagai standard dalam pengukuran gejala dan karakteristik kekhawatiran berkaitan dengan kelainan dalam perilaku makan. EAT-26 terdiri dari 3 dimensi, yaitu: Dieting, Bulimia, and Food Preoccupation and Oral Control. ${ }^{6}$

Pengukuran aktivitas fisik dilakukan dengan menggunakan kuesioner adaptasi The Questionnaire for Measurement of a Person's Habitual Physical Activity (QMPHPA). Kuesioner yang dikembangkan oleh Baecke. ${ }^{7}$ digunakan secara khusus untuk mengevaluasi aktivitas fisik individu dengan membagi aktivitas fisik dari individu tersebut ke dalam 3 dimensi, yaitu: work activity, sports activity, dan leisure activity.

Dalam penelitian ini peneliti menggunakan beberapa kuesioner dengan bahasa asing (MBSRQ-AS, SATAQ-3, EAT-26, dan QMPHPA). Oleh sebab itu sebelum menggunakan semua alat ukur tersebut, maka perlu dilakukan proses adaptasi bahasa terlebih dahulu, agar sesuai dengan bahasa yang digunakan oleh responden dalam penelitian ini.

Sebelum pengumpulan data dilaksanakan, terlebih dahulu peneliti melakukan survei awal dan uji coba kuesioner. Uji coba kuesioner dilakukan terhadap 125 responden. Tujuan dari uji coba kuesioner untuk mengetahui kekurangan dari kuesioner sehingga dapat dilakukan perbaikan agar kuesioner lebih mudah dimengerti oleh responden saat pengumpulan data.

Tipe validitas yang digunakan dalam penelitian ini adalah validitas konsep (construct validity). Validitas konstruk adalah tipe validitas yang menunjukkan sejauh mana tes mengungkap suatu trait atau konstruk teoritik yang hendak diukurnya. ${ }^{8} \quad \mathrm{Uji}$ validitas dilakukan dengan membandingkan nilai component dengan batas signifikan sebesar $0.5 .^{9}$ Jika nilai component lebih besar dari batas signifikan maka butir pertanyaan atau indikator tersebut dinyatakan valid.

Reliabilitas/keandalan adalah alat ukur untuk mengukur suatu kuesioner yang merupakan indikator dari variabel atau konstruk. Suatu kuesioner dikatakan reliabel atau handal jika jawaban seseorang (responden) terhadap pertanyaan adalah konsisten atau stabil dari waktu ke waktu. Uji reliabilitas dalam penelitian ini dinyatakan dengan melihat nilai Cronbach Alpha $(\alpha)$. Suatu variabel dikatakan reliabel jika memberikan nilai Cronbach Alpha > 0.6. ${ }^{10}$

\section{HASIL}

Pengukuran IMT untuk menilai status gizi seseorang dapat dilakukan dengan cepat dan tanpa biaya yang mahal. ${ }^{11}$ Analisis univariat dilakukan untuk mengetahui gambaran distribusi frekuensi dari setiap variabel yang dikaji pada penelitian ini yaitu pengaruh media massa, pengaruh teman, citra tubuh, perilaku makan, aktivitas fisik, dan IMT. Rekapitulasi hasil uji univariat dapat dilihat pada Tabel 1.

\section{Tabel 1. Rekapitulasi Hasil Uji Univariat}




\begin{tabular}{|c|c|c|c|c|}
\hline Variabel & $\begin{array}{c}\text { Mean } \\
\text { Median }\end{array}$ & $\begin{array}{c}\text { Standard } \\
\text { Deviasi }\end{array}$ & Minimal - Maksimal & $95 \%$ CI of Mean \\
\hline Berat Badan (kg) & $\begin{array}{l}54,340 \\
51,700\end{array}$ & 11,087 & $34,0-97,7$ & $52,925-55,756$ \\
\hline Tinggi Badan $(\mathrm{cm})$ & $\begin{array}{l}156,498 \\
156,100\end{array}$ & 5,330 & $141,8-170,9$ & $155,818-157,179$ \\
\hline $\begin{array}{l}\text { Indeks Massa Tubuh } \\
(\mathrm{kg} 2 / \mathrm{m})\end{array}$ & $\begin{array}{l}22,186 \\
21,248\end{array}$ & 4,383 & $13,31-39,05$ & $21,626-22,746$ \\
\hline Pengaruh Media Massa & $\begin{array}{l}85,61 \\
85,00\end{array}$ & 16,610 & $30-131$ & $83,49-87,73$ \\
\hline Pengaruh Teman & $\begin{array}{l}33,88 \\
34,00\end{array}$ & 9,982 & $7-68$ & $32,60-35,15$ \\
\hline Citra Tubuh & $\begin{array}{l}107,02 \\
107,00\end{array}$ & 10,223 & $74-147$ & $105,72-108,33$ \\
\hline Perilaku Makan & $\begin{array}{l}11,30 \\
10,00\end{array}$ & 8,126 & $0-72$ & $10,26-12,34$ \\
\hline Aktivitas Fisik & $\begin{array}{l}7,276 \\
7,250\end{array}$ & 0,962 & $4,25-10,63$ & $7,153-7,399$ \\
\hline
\end{tabular}

Melalui pengukuran antropometri dihasilkan nilai rata-rata masing-masing untuk $\mathrm{BB}$ dan $\mathrm{TB}( \pm \mathrm{SD})$ adalah sebesar $54,340 \pm 11,087 \mathrm{Kg}$ dan $156,498 \pm$ $5,330 \mathrm{~cm}$. Hasil analisis terhadap variabel IMT didapatkan rata-rata IMT ( \pm SD) adalah 22,186 \pm 4,383. Pengukuran pengaruh media massa dengan menggunakan SATAQ-3 dihasilkan nilai rata-rata $( \pm$ SD) adalah sebesar 85,61 $\pm 16,610$. Pengaruh teman diukur dengan menggunakan kuesioner sikap terhadap pengaruh teman, dihasilkan rata-rata $( \pm$ SD) adalah sebesar $33,88 \pm 9,982$. Nilai rata-rata $( \pm \mathrm{SD})$ citra tubuh yang diukur dengan menggunakan MBSRQ-AS adalah sebesar $107,02 \pm 10,223$. Sementara itu, perilaku makan yang diukur dengan menggunakan EAT-26 dan aktivitas fisik yang diukur dengan menggunakan QMPHPA, diperoleh nilai rata-rata $( \pm$ SD) masing-masing adalah $11,30 \pm 8,126$ dan 7,276 \pm 0,962 .

Sementara itu, rekapitulasi pengkategorisasian untuk masing-masing variabel dapat dilihat pada tabel berikut. IMT dikategorisasikan dengan menggunakan klasifikasi IMT menurut $\mathrm{CDC}^{12}$ Sedangkan pengkategorisasian untuk variabel pengaruh media massa, pengaruh teman, citra tubuh, dan aktivitas fisik secara kuantitatif dilakukan dengan menentukan panjang kelas melalui perhitungan hasil rekapitulasi skor masing-masing alat ukur dari variabel-variabel tersebut. Pengkategorian untuk variabel perilaku makan berdasarkan skor EAT-26 berdasarkan klasifikasi yang telah ditentukan oleh Garner. ${ }^{6}$
Dari tabel di atas dapat dilihat bahwa dari 238 siswi SMA Negeri 12 Jakarta Timur kelas X dan XI, sebagian besar $(73,5 \%)$ berada pada kategori IMT Normal (175 orang), sedangkan untuk kategori IMT Underweight, obesitas, dan Overweight masing-masing sebesar $4,6 \%$ (11 orang), 8,4\% (20 orang), dan 13,4\% (32 orang). Pada distribusi frekuensi kategori pengaruh media massa terlihat bahwa variasi kategorinya hampir bersifat homogen dimana perbandingan siswi yang terpengaruh dengan yang tidak terpengaruh oleh media massa hampir seimbang dengan jumlah siswi yang terpengaruh oleh media massa adalah sebanyak 141 orang $(59,2 \%)$ sedangkan siswi yang tidak terpengaruh oleh media massa sebanyak 97 orang $(40,8 \%)$. Pada distribusi frekuensi kategori pengaruh teman diketahui bahwa sebagian besar $(65,1 \%)$ siswi berada pada kategori tidak terpengaruh oleh teman dan siswi yang berada pada kategori terpengaruh oleh teman terdapat sejumlah 83 orang $(34,9 \%)$. Sedangkan untuk citra tubuh, terlihat bahwa sebagian besar $(66,8 \%)$ siswi berada pada kategori citra tubuh negatif dan siswi yang berada pada kategori citra tubuh positif terdapat sejumlah 79 orang $(33,2 \%)$, dengan $12,6 \%$ responden berperilaku makan buruk dan $87,4 \%$ berperilaku makan baik. Aktivitas fisik responden sebagian besar berada pada kategori aktivitas fisik rendah $(60,1 \%)$, sedangkan $39,9 \%$ responden lainnya memiliki aktivitas fisik yang tinggi.

\section{Tabel 2. Rekapitulasi Hasil Kategorisasi Variabel}




\begin{tabular}{cccc}
\hline Variabel & Kategori & $\mathbf{n}$ & $\mathbf{\%}$ \\
\hline \multirow{3}{*}{ IMT } & Underweight & 11 & 4,6 \\
& Normal & 175 & 73,5 \\
& Overweight & 32 & 13,4 \\
& Obesitas & 20 & 8,4 \\
\hline \multirow{2}{*}{ Pengaruh Media Massa } & Tidak Terpengaruh & 97 & 40,8 \\
& Terpengaruh & 141 & 59,2 \\
\hline \multirow{2}{*}{ Pengaruh Teman } & Tidak Terpengaruh & 155 & 65,1 \\
& Terpengaruh & 83 & 34,9 \\
\hline \multirow{2}{*}{ Citra Tubuh } & Negatif & 159 & 66,8 \\
& Positif & 79 & 33,2 \\
\hline \multirow{2}{*}{ Perilaku Makan } & Buruk & 30 & 12,6 \\
& Baik & 208 & 87,4 \\
\hline \multirow{2}{*}{ Aktivitas Fisik } & Rendah & 143 & 60,1 \\
& Tinggi & 95 & 39,9 \\
\hline
\end{tabular}

Diagram jalur akhir yang didapatkan melalui penelitian pengaruh citra tubuh, perilaku makan, dan aktivitas fisik terhadap IMT pada siswi kelas X dan XI SMA Negeri 12 Jakarta Timur tahun 2014 adalah pada gambar berikut. Dari hasil perhitungan dengan analisis jalur dapat diketahui bahwa yang mempunyai pengaruh signifikan pada citra tubuh adalah variabel pengaruh media massa $(\beta=0.20, p<0,05)$. Sementara itu yang mempunyai pengaruh signifikan pada perilaku makan adalah variabel pengaruh media massa $(\beta=0.24$, $p<0,01)$ dan citra tubuh $(\beta=0.19, p<0,01)$. Sedangkan variabel pengaruh teman berpengaruh signifikan terhadap IMT $(\beta=0.37, p<0,01)$.

Pengaruh positif dalam model diagram jalur digambarkan dengan garis yang jelas, sedangkan pengaruh negatif terlihat digambarkan dengan garis putus-putus. Hal ini terlihat pada pengaruh langsung variabel media massa terhadap variabel aktivitas fisik dan IMT, pengaruh langsung variabel citra tubuh terhadap IMT, dan pengaruh langsung variabel perilaku makan terhadap IMT. Melalui penelitian dapat dilihat bahwa dari variabel pengaruh media massa dan pengaruh teman berpengaruh langsung terhadap variabel citra tubuh, dengan pengaruh variabel lain di luar penelitian ini $\left(e_{1}\right)$ sebesar 90,5\%. Terlihat juga bahwa variabel citra tubuh tidak memberikan pengaruh langsung terhadap IMT, hal ini terlihat dari nilai pengaruh langsungnya yang sangat kecil (lihat Gambar 1). Citra tubuh mempengaruhi IMT secara tidak langsung melalui variabel perilaku makan, aktivitas fisik, maupun keduanya. Pengaruh citra tubuh terhadap IMT terbesar adalah melalui variabel perilaku makan dan variabel aktivitas fisik dengan total pengaruh sebesar $25,8 \%$.

Melalui model diagram jalur di atas diperoleh persamaan struktural sebagai berikut:

$\mathrm{Y}_{1}=0,199 \mathrm{X}_{1}+0,146 \mathrm{X}_{2}+\mathrm{e}_{1}$

$\mathrm{Y}_{2}=0,236 \mathrm{X}_{1}+0,102 \mathrm{X}_{2}+0,191 \mathrm{Y}_{1}+\mathrm{e}_{2}$

$\mathrm{Y}_{3}=-0,014 \mathrm{X}_{1}+0,058 \mathrm{X}_{2}+0,003 \mathrm{Y}_{1}+0,050 \mathrm{Y}_{2}+\mathrm{e}_{3}$

$\mathrm{Y}_{4}=-0,146 \mathrm{X}_{1}+0,374 \mathrm{X}_{2}-0,006 \mathrm{Y}_{1}-0,028 \mathrm{Y}_{2}+$ $0,017 \mathrm{Y}_{3}+\mathrm{e}_{4}$ 
Gambar 1. Model Diagram Jalur Penelitian Pengaruh Citra Tubuh, Perilaku Makan, dan Aktivitas Fisik terhadap IMT Siswi SMA Kelas X dan XI Tahun 2014

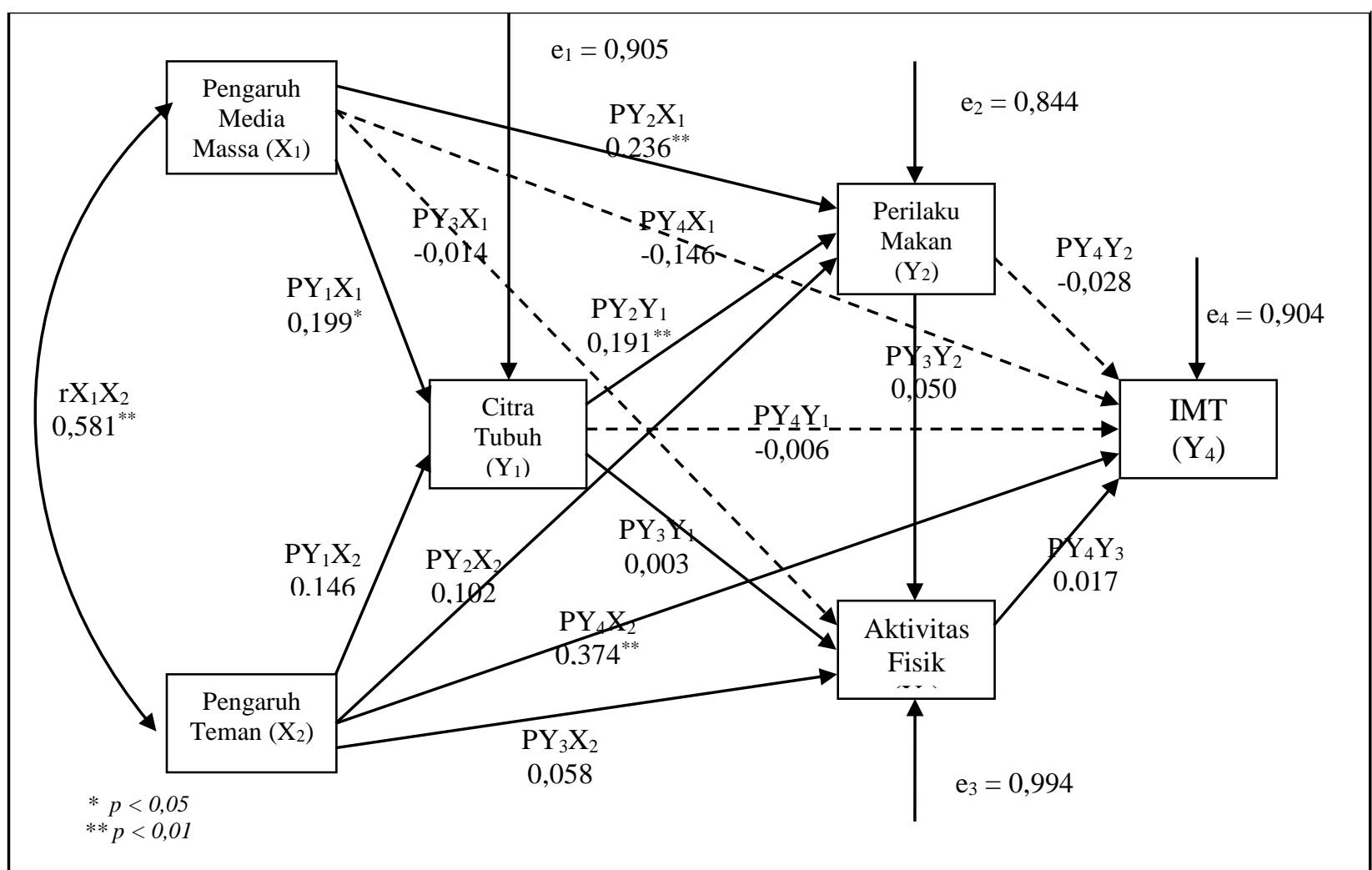

\section{DISKUSI}

Indeks massa tubuh yang normal pada usia remaja dapat menghindarkan dari kondisi penyakit yang terkait gizi pada usia remaja. Banyak faktor yang mempengaruhi status gizi pada remaja. Faktor-faktor yang mempengaruhi status gizi pada dasarnya ditentukan oleh faktor internal dan eksternal. Faktor internal terdiri dari genetik, asupan makanan, dan faktor penyakit. Faktor eksternal dapat terdiri dari faktor ekonomi, faktor sosial budaya, dan pengetahuan gizi.

Seiring dengan perkembangan teknologi, penggunaan bahan kimia dalam proses pembuatan makanan semakin marak. Penggunaaan hormon dalam perkembangbiakan hewan ternak akan mempengaruhi pertumbuhan remaja. Remaja yang mengkonsumsi produk makanan tersebut cenderung menjadi gemuk dan memiliki Indeks Masa Tubuh yang tinggi pula. Hal ini terlihat dari makin maraknya restoran cepat saji yang menyediakan junk food yang justru malah menjadi "idola" di kalangan remaja putri. Masih cukup tingginya kasus overweight dan obesitas di tempat penelitian menunjukkan masih terdapatnya masalah gizi pada sebagian responden.

Menurut penelitian Wang, Worsley, dan Cunningham yang berjudul Social ideological influences on reported food consumption and BMI, dijelaskan bahwa status gizi (dalam hal ini ditunjukkan melalui IMT) dipengaruhi oleh perilaku makan, sedangkan perilaku makan dipengaruhi oleh pendapat tentang pentingnya kesehatan. ${ }^{13}$ Pendapat tersebut dipengaruhi oleh sikap atau persepsi tentang kesehatan yang dipengaruhi oleh ideologi yang berupa egalitarian, materialism, dan feminitas.

Pada penelitian yang dilakukan oleh Hoyt dan Kogan menunjukkan bahwa terdapat hubungan yang signifikan antara pengaruh media massa terhadap ketidakpuasan citra tubuh. ${ }^{14}$ Penampilan dan bentuk tubuh yang ideal dari model yang terdapat pada media massa, baik cetak maupun elektronik, telah membuat para remaja wanita dan wanita dewasa menilai negatif (tidak puas) terhadap penampilan fisik mereka. Konsumsi media yang tinggi dapat mempengaruhi konsumen. Melalui hasil observasi mengenai aktivitas responden saat waktu luang juga didapatkan bahwa 
hampir seluruh responden menghabiskan waktu luang mereka dengan menonton TV. Hal ini membuat para siswi kelas X dan XI lebih sering terpapar oleh iklan dan program TV yang dapat mempengaruhi citra tubuhnya.

Sementara itu, hubungan interpersonal membuat seseorang cenderung membandingkan diri dengan orang lain dan feedback yang diterima mempengaruhi konsep diri termasuk mempengaruhi bagaimana perasaan terhadap penampilan fisik. Hal ini sejalan dengan pendapat yang menyatakan bahwa feedback terhadap penampilan serta kompetisi teman sebaya dan keluarga dalam hubungan interpersonal dapat mempengaruhi bagaimana pandangan dan perasaan mengenai bentuk tubuh. ${ }^{15}$

Remaja yang memiliki citra tubuh yang positif akan merasa bahwa tubuh dan penampilannya menarik. Perasaan ini muncul karena remaja memiliki rasa percaya diri yang tinggi. Walaupun pada kenyataannya tubuh dan penampilannya kurang menarik, tetapi remaja tersebut tidak diliputi perasaan depresi, gagal atau kebencian pada diri sendiri karena tubuh dan penampilannya yang menarik bukan merupakan satusatunya syarat agar mereka memperoleh pengakuan dari lingkungan dan teman sebayanya sehingga tidak menutup kemungkinan mereka akan memiliki perilaku makan yang tidak baik. Perilaku makan yang tidak baik ini dapat terjadi karena banyak siswi yang tidak memiliki keteraturan dalam hal makan atau tidak jarang siswi makan bukan untuk tujuan memenuhi rasa lapar, melainkan lebih kepada pemenuhan kebutuhan psikologis dan sosialisasi. Jadi meskipun remaja memiliki citra tubuh positif belum tentu memiliki perilaku makan yang baik, dan begitu pula sebaliknya.

Pada penelitian ini juga dapat dilihat bahwa remaja yang memiliki citra tubuh yang positif akan merasa bahwa tubuh dan penampilannya menarik. Perasaan yang menyenangkan ini muncul karena remaja memiliki rasa percaya diri yang tinggi. Walaupun pada kenyataannya tubuh dan penampilannya kurang menarik, tetapi individu tersebut tidak diliputi perasaan depresi, gagal atau kebencian pada diri sendiri karena tubuh dan penampilannya yang menarik bukan merupakan satu-satunya syarat agar mereka memperoleh pengakuan dari lingkungan dan teman sebayanya.

Hasil penelitian kami yang berkaitan dengan aktivitas fisik responden menunjukkan hasil yang bertolak belakang dengan penelitian yang dilakukan oleh Ingledew dan Sullivan. ${ }^{16}$ Hasil penelitian mereka menyebutkan bahwa aktivitas fisik seorang remaja dipengaruhi oleh efek biopsikologis diantaranya adalah persepsi mengenai bentuk tubuh remaja itu sendiri yang dalam kaitannya dengan penelitian ini adalah citra tubuh remaja itu sendiri. Remaja putri khususnya sering mengalami persaingan antar teman dalam usaha membentuk dan mempercantik tubuhnya. Persaingan dan pengaruh antar teman sebaya ini juga dapat menjadi motif seorang remaja putri untuk melakukan aktivitas fisik dalam bentuk olahraga guna mencapai bentuk tubuh yang ideal seperti yang mereka idamkan, baik meniru bentuk tubuh artis idolanya maupun teman atau kerabat dekatnya. Aktivitas fisik yang terlalu berlebihan juga dapat dipengaruhi oleh perilaku makan yang salah, dimana menurut Ingledew dan Sullivan, remaja cenderung melakukan aktivitas fisik yang berlebih guna mengontrol berat badannya. ${ }^{16}$

Dalam penelitian ini, citra tubuh tidak dapat menunjukkan pengaruhnya secara langsung terhadap IMT dikarenakan citra tubuh yang merupakan bentuk persepsi dari ukuran dan bentuk tubuh seorang remaja terlalu luas untuk dilihat pengaruhnya dengan hanya melalui pengukuran IMT. Aspek-aspek pengukuran IMT hanya merupakan sebagian daripada aspek-aspek yang terkandung dalam pengukuran citra tubuh dalam penelitian ini. Aspek lainnya yang terukur melalui citra tubuh (misal: evaluasi penampilan, orientasi penampilan, maupun kepuasan terhadap bagian tubuh) tidak mampu dijelaskan melalui pengukuran antropometri. Hanya aspek kecemasan menjadi gemuk dan persepsi mengenai ukuran/berat badan saja yang bisa dijelaskan melalui pengukuran IMT.

Perilaku makan adalah faktor langsung yang memengaruhi asupan makanan. Perilaku makan dalam hal ini meliputi frekuensi makan, jenis makanan yang dikonsumsi, kebiasaan pada saat makan, dan juga ratarata banyaknya makanan yang dikonsumsi setiap hari. Perilaku makan yang baik maupun tidak baik akan mempengaruhi IMT dan pada akhirnya akan berdampak pada status gizi individu. Schroeder menyatakan bahwa salah satu faktor langsung yang memengaruhi status gizi individu adalah cukup atau tidaknya asupan makanan. ${ }^{17} \mathrm{Hal}$ ini juga sesuai dengan konsep masalah gizi yang dikemukakan UNICEF bahwa penyebab langsung terjadinya masalah gizi adalah asupan makanan dan penyakit infeksi. ${ }^{18}$

\section{Kesimpulan}

Terdapatnya pengaruh tidak langsung citra tubuh terhadap IMT melalui perilaku makan dan aktivitas 
fisik pada siswi kelas $\mathrm{X}$ dan XI SMA Negeri 12 Jakarta, namun masih harus dilihat bagaimana perilaku makan serta aktivitas fisik yang dilakukan oleh siswi tersebut. Selain itu pengaruh media massa, pengaruh teman, dan citra tubuh memberikan pengaruh langsung maupun tidak langsung terhadap perilaku makan. Hal ini berarti bahwa media massa, teman, dan citra tubuh berkontribusi terhadap pembentukan perilaku makan pada siswi kelas X dan XI SMA Negeri 12 Jakarta Timur.

Adanya pengaruh signifikan antara pengaruh media massa dan citra tubuh terhadap perilaku makan maka perlu adanya adanya upaya untuk membangun keyakinan hidup sehat berkaitan dengan berat badan, bentuk tubuh, perilaku makan yang baik serta gizi seimbang. Internalisasi mengenai persepsi bentuk tubuh ideal yang sehat perlu ditanamkan dalam diri remaja siswi SMA di tempat penelitian. Usaha-usaha promotif dan preventif untuk membangun kesadaran bahwa tubuh yang ideal seperti yang mereka inginkan dapat dicapai melalui usaha-usaha yang baik tanpa harus merugikan diri sendiri terutama kesehatan mereka.

Perlunya diadakan penelitian yang lebih spesifik lagi berkaitan dengan pengaruh media massa, pengaruh teman, citra tubuh, perilaku makan, dan aktivitas fisik pada siswi SMA di Indonesia dengan metode kualitatif agar dapat diketahui konstruk/dimensi untuk setiap variabel, sehingga instrumen yang digunakan sebagai alat ukur dapat dengan tepat mengukur fenomena yang terjadi berkaitan dengan setiap variabel tersebut sesuai dengan kondisi budaya dan norma yang ada di Indonesia. Penambahan variabel lainnya seperti sosiokultural ekonomi responden, pengaruh keluarga, norma dan budaya, moralitas, serta variabel lainnya yang berkaitan dengan citra tubuh, perilaku makan, dan aktivitas fisik responden agar dapat diolah dan mendapatkan hasil penelitian yang lebih komprehensif lagi.

\section{Daftar Referensi}

1. Stice, E., Spangler, D., dan Agras, W.S. (2001). Exposure to Media-Portrayed Thin-Ideal Images Adversely Affects Vulnerable Girls: A Longitudinal Experiment. Journal of Social and Clinical Psychology. 20(3): 270-288.

2. Bessenoff, G.R. (2006). Can the Media Affect Us? Social Comparison, Self-Discrepancy, and the Thin Ideal. Psychology of Women Quarterly. 30: 239-251.

3. Purwaningrum. (2008). Hubungan Antara Citra Raga dengan Perilaku Makan Remaja Putri. Skripsi. Surakarta: Fakultas Psikologi Universitas Muhammadiyah

4. Cash, T.F. dan Pruzinsky, T. (2002). Body Image: A Handbook of Theory, Research, and Clinical Practice. Guildford Press.

5. Thompson, J. K., van den Berg, P., Roehrig, M., Guarda, A. S., dan Heinberg, L. J. (2004). The Sociocultural Attitudes Toward Appearance Scale-3 (SATAQ-3): Development and validation. International Journal of Eating Disorders, 35, 293-304

6. Garner, D.M. (1993). Self-report measures for eating disorders. Current Content, Social and Behavioral Sciences.

7. Baecke, J.A.H., Burema, J., dan Frijters, E.R. (1982). A Short Questionnaire for the Measurement of Habitual Physical Activity in Epidemiological Studies. Am J Clin Nutr. 36: 936-942.

8. Azwar, S. (2010). Penyusunan Skala Psikologi. Yogyakarta: Pustaka Pelajar.

9. Santoso, S. (2007). Structural Equation Modelling. Jakarta : PT. Elex Media Komputindo.

10. Sekaran, U. (2003). Research Methods for Business : A Skill Building Approach. New York: John Wiley and Sons Inc.

11. Eknoyan, G. (2008). Adolphe Quetelet (17961874)_-The Average Man and Indices of Obesity. Nephrol Dial Transplant. 23, pp.47-51.

12. CDC. (2013). Using the BMI-for-age Growth Charts. Atlanta: Clifton Rd.

13. Wang, W.C., Worsley, A., dan Cunningham, E.G. (2008). Social Ideological Influences on Reported Food Consumption and BMI. Int $\mathbf{J}$ Behav Nutr Phys Act. 5:20.

14. Hoyt, W.D. dan Kogan, L.R. (2002). Satisfaction with body image and peer 
relationships for males and females in a college environment. Sex Roles, 45, 3 / 4, 199-215

15. Cash, T.F. (2000). The Multidimensional BodySelf Relation Questionnaire: MBSRQ User's Manual 3rd Revision). Virginia: Old Dominion, University Norfolk.

16. Ingledew, D.K. dan Sullivan, G. (2002). Effects of body mass and body image on exercise motives in adolescence. Psychology of Sport and Exercise. 3 (2002):323-338.

17. Schroeder, D.G. (2001). Malnutrition, Nutrition, and Health in Developing Countries. Ed: Richard D. Semba and Martina W. Bloem. Ottowa: Humana Press.

18. Gibney, et al. (2009). Gizi Kesehatan Masyarakat. Jakarta: EGC. 